\title{
A SURFACE STRUCTURE (?) IN NORMAL NUCLEATED ERYTHROCYTES
}

\author{
SAVAS NITTIS \\ Thomas Henry Simpson Memorial Institute for Medical Research, University of \\ Michigan, Ann Arbor, Michigan \\ T'WO FIGURES
}

In studying erythrocytes of the blood of animals in which these cells are found in circulation in the nucleated form, a 'stigma' was observed when the cells were 'supravitally' stained and kept in the wet condition. ${ }^{1}$ This structure apparently does not fit into any eategory of the many 'granules' previously described. In using brilliant cresyl blue as a supravital stain in the study of the blood of the frog, the pigeon, the horned toad (Phrynosoma solare), and the snake, this stigma stained a deep blue and was situated on the surface of the cell, eccentrically. It was a constant finding on each and every erythrocyte, it being the same size or slightly smaller than the specific granules of a human eosinophile. As a rule, it was situated on the upper surface of the cell. Its periphery was sharply outlined, in contrast to the granules observed within the cytoplasm in connection with, or independently of, the reticulum. When the cells were stained under the microscope and the different stages of staining were followed by the observer, this stigma was the first to take the stain; then the nucleus was stained; that was followed by the reticulum and, lastly, by the appearance of another stigma. This second stigma was smaller than the first, and in small, nucleated erythrocytes it could not be

'Stigma is the Greek word for 'mark' or 'dot.' In this paper it is used as a general deseriptive term and does not imply any particular morphological signifieance. 
distinguished very readily, unless one had been accustomed to its observation in larger cells. In the smaller erythrocytes (pigeon) both stigmata were easily confused with the granules that appear within the meshes of the reticulum, but the larger one, owing to its property of taking up the stain first (or alone, when there is not sufficient quantity to stain any part of the reticulum), could always be distinguished from any other element of the erythrocyte. The second stigma is generally smaller than the first and it lies on the opposite surface of the cell-as a rule, the lower. Its size is about one-half or three-fourths of that of the first stigma. The two stigmata never appeared to be situated on the same plane, and when one was visible, the other was out of focus. The distance between the two, as estimated by the focusing of the microscope, was similar to the approximate thickness of the erythrocyte. They were a constant finding on every nucleated reticulated erythrocyte. They were first observed in wet, supravitally stained preparations that were prepared by the following technic.

\section{METHODS}

With a diamond point a groove was made on an ordinary slide, extending from the one end to the middle. This was widened and deepened with the corner of another slide, the end of the groove being made as smooth as possible. A small drop of blood was placed on a cover-slip, which was inverted and dropped on the slide, so that the drop of blood fell on the end of the groove. It was found of great importance to have a drop of blood of minimal size, so that the blood would not spread to the edges of the cover-slip. A drop that ultimately covers but one-third of the cover-slip's surface is best suited for these studies. The end of an ordinary medicine dropper was drawn to a long capillary pipette as thin as could be obtained. A drop of stain was deposited into this pipette. The end was then inserted into the groove on the slide between cover-slip and slide and, by means of the rubber bulb of the dropper, a minute droplet of stain (usually so 
small that it was barely visible) was squeezed into the mass of the cells. Additional injections of stain were added from time to time, as the cells that lay around the stain were studied.

A second method used was as follows: A small drop of blood is placed on the cover-slip and this inverted and dropped onto an ordinary slide. (As before, the blood should not spread to the edges of the cover-slip.) The specimen is brought under the microscope and under observation. A drop of the brilliant-cresyl-blue solution in 0.85 per cent sodium chloride is deposited on the slide near the edge of the cover-slip. The stain readily spreads under the cover-slip and surrounds the blood. Although the cells at the outer rim take the stain too readily, one can follow the different stages of staining by moving the field from the edge to the middle of the blood-covered area.

The larger or first stigma to appear is best demonstrated in the following manner: To a small number of erythrocytes suspended in their serum, brilliant-cresyl-blue saturated solution in 0.85 per cent sodium chloride is added drop by drop. A few cells are examined microscopically with every additional amount of stain. It will be observed that when the suspension takes a slightly bluish tinge, the cells exhibit a brightly stained blue stigma, while the reticulum and the nucleus are as yet wholly unstained. A good result is obtained when $0.40 \mathrm{cc}$. of the saturated brilliant-cresyl-blue solution is mixed with $2.0 \mathrm{cc}$. of blood. The number of erythrocytes present is not important, as the staining capacity of the dye was found to be proportional to the total volume of the blood, and not to the number of cells present. (Figure 1 is a film from such a suspension of pigeon's blood. Compare the brightly stained stigma with the unstained nucleus and reticulum.) 


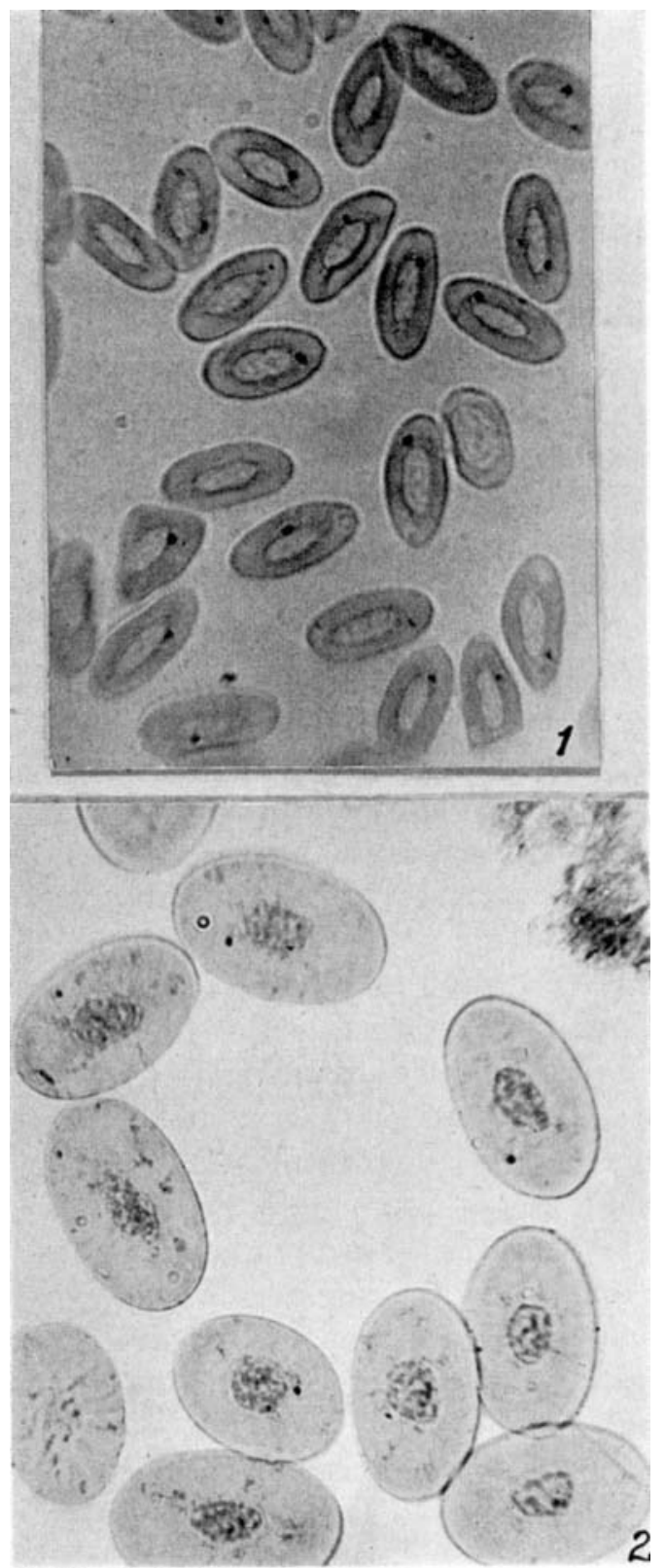

Figures 1 and 2 


\section{OBSERVATIONS}

With these procedures of staining, it was noticed that when the stain was present in minute quantities, the cells exhibited one brightly stained stigma that, as a rule, lay on the upper surface and favored the smaller axis of the cell. When more of the dye was injected, there appeared a thread-like line of particles that extended from underneath this stigma to the nucleus. After the reticulum appeared, this line or thread could not be separately identified. Occasionally small 'granules' interrupted the course of this thread. These granules were usually slightly smaller and, in contrast to the first stigma, showed lively brownian movements. The nucleus then took the stain. But not until it was completely dyed did the reticulum start taking the stain. This process was followed and apparently completed by the appearance of the other stigma, which as a rule was smaller and lay on the lower surface of the erythrocytic 'membrane.' When the cells were not too heavily stained, the first stigma was much more deeply stained than the rest of the cell (fig. 2). Every single, reticulated, nucleated erythrocyte presented these stigmata and took the stain in this identical manner, irrespective of the species of the animal (frog, pigeon, horned toad, or snake).

In human blood the small number of the nucleated erythrocytes found in circulation made this kind of study, and hence the demonstration of these stigmata, impossible. They could

Fig. 1 Pigeon's blood. Dry film. Two cubic centimeters of pigeon's blood were mixed with 0.40 ce. saturated solution of brilliant eresyl blue in 0.85 per cent sodium chloride. The stigma is deeply stained, while the nueleus has not yet taken the stain.

Fig. 2 Snake's blood. Wet preparation. 'Supravital' staining with brilliant cresyl blue. The red blood cells are completely stained. The nucleus and roticulum are not as heavily stained as the stigma, which appears almost black. Owing to the fact that this was a wet preparation with the cells floating in the fluid, the stigmata of all the cells could not be brought into focus at one time.

The photographs are not retouched and therefore the pictures show some extracellular particles. The stigmata, however, can easily be recognized from their much deeper color. 
not be demonstrated in reticulated human erythrocytes, but their existence was suspected. The human reticulated erythrocyte when found in circulation is an abnormal cell, in contrast to the erythrocyte of amphibian, reptilian, and avian origin, where the nucleated and reticulated cell is the adult form. When they are present in sufficient numbers to make the observation practicable, as in pernicious anemia during early remission, the erythrocytes are largely of pathologic shape and this distortion greatly hinders the search for similar structures.

In pigeons, following an intravenous injection of $5.0 \mathrm{cc}$. of saturated solution of brilliant cresyl blue in 0.85 per cent sodium chloride (the birds died during the injection and the blood was removed from a large blood vessel or directly from the heart), all the red blood cells exhibited one brightly stained stigma and not one showed a stained nucleus or reticulum. When more stain was added to these cells, they stained in the usual way.

In specimens stained supravitally first and then with the Wright's stain, these stigmata are not recognizable. It appears that they lose the stain during the process of the Wright staining.

For further study of these findings, some supravitally stained wet specimens of blood from a horned toad were sealed with petrolatum or Canada balsam and kept in the icebox. Canada balsam was the more practical to use and it did not seem to affect the cells differently than the petrolatum, for the dry borders of the blood seemed to prevent its mixing with the cells that were still in the wet state. On subsequent examinations, it was found that some of the cells were laked, while the reticulum, the stigmata, and the nucleus were preserved in excellent condition. These cells offered an excellent opportunity for study of the relation of these stigmata to the nucleus and the reticulum. It was plainly apparent that the first and brighter and usually upper stigma was connected with the nucleus by means of a thin thread that seemed to be part of the reticulum. 
The larger size of the cells of the horned toad and the clearer arrangement of the meshes of their reticular net permitted a better study of these stigmata, and it was in these cells that the observation was first made. However, all the observations upon the erythrocyte of the horned toad were readily confirmed in the amphibian and the avian erythrocyte.

\section{DISCUSSION}

Undoubtedly the first stigma described above has been seen by other observers, either alone or together with other 'granules' that were erroneously thought to be of similar structure and nature. It appears that the first observer was Schultze(1), who put live triton larvae in aqueous methyleneblue solutions of from 1:100,000 to 1:1,000,000. He described a blue granule that could also be seen in the unstained blood of the same larvae. Similarly, Fischel(2) experimented with live amphibian larvae by immersing them in weak aqueous solutions of vital stains. In figure 33 of his paper he shows a blood vessel filled with red blood cells each containing a small number of stained dots. One of them must of necessity be identical with the one here described, but it is not separately recognized by the author. It would not be necessary to discuss the nature of the findings described previously by Bremer(3) and Dehler(4) if their observations had not been misinterpreted by other authors. Bremer used unstained preparations of turtle blood, while Dehler made his studies on the blood of the chick embryo in paraffin-fixed tissue. Since the stigmata do not appear in fixed specimens, and the pictures shown by Dehler do not even remotely suggest any similarity or resemblance to stigmata, and inasmuch as Bremer later(5) identified Dehler's findings with his own, it is believed that the structures described by these authors do not correspond to the ones here described. In the author's opinion, Bremer's findings are exactly identical with Ranvier's(6) 'vacuoles spheriques' observed in the fresh blood of the frog. Both Bremer and Dehler agreed that the struc- 
tures they observed represent a form of centrosome. Such 'centrosomes' Apáthy (7) observed in the blood of full-grown salamanders in air-dried, fixed, and stained specimens. Weidenreich(8) considered the granules or globules observed by himself and others as artefacts. Meves(9), experimenting with the blood of salamanders vitally stained with methylene blue, apparently described the larger stigma correctly, but stated that "instead of one only, one observes frequently two or three and even a greater number of corresponding smaller granules (Kügelchen)." He called the whole group 'chromatoid granules' and identified them with the structures observed by Apáthy, Schultze, and Fischel, but disagreed with them and also with Bremer and Dehler in interpreting them as 'centrosomes.' He thought that they might represent "rejected and 'corrupted' nucleoli." In any case, their strong reaction to the supravital stains was for him a proof of their being 'dead elements.' Even in more recent articles this structure has been confused with many elements from which it could easily be separated. Schilling (10) described 'small, dark chromatin grains' found on his 'Kapselkörper' in man and other mammals and associated them with the granules or groups of granules described by the aforementioned authors. He believed them all to be 'centrosomes.' Jolly $(11,12,13)$ noted this vitally demonstrated stigma in normal nucleated erythrocytes as single granules or multiple droplets. He distinguished his structures from the 'brilliant granules' of Ranvier, but identified them with Apáthy's and Bremer's. He suggested that they represented a form of centrosome or that they were formed by transformation of a chromosome. Isaacs'(14) 'refractive granule' as found in non-nucleated erythrocytes is of different nature, whether demonstrated in the fresh state or after the preparation is fixed and stained. Jordan(15), after staining erythrocytes of the frog with neutral red, observed "a variable number of small red-stained spherical granules and globules, some of which exhibited brownian movements." Lewis and Lewis(16), who observed supravitally stained 
granules in the blood of fish, amphibians, and reptiles, distinguished between 'granules' and 'vacuoles' in their specimens. Chlopin(17) identified the 'few enclosures' that he obtained after placing live axolotls in a weak solution of neutral red over a long period of time with the 'vacuolelike shapes (formations)' that he observed in fixed and stained preparations, as well as with the different structures observed by other authors. Dawson $(18,19)$ thinks that the pre-existing granules of what he calls "segregation apparatus of the red blood cells" are typically grouped as bipolar clusters which may be seen in fresh blood and are readily demonstrated as basophilic bodies in smears stained with Wright's or Giemsa's stains. Although he makes distinction between the pre-existing and the induced granules and globules, he fails to recognize separately the stigmata here described and which cannot be stained or counterstained with the Wright's stain.

The separate identity of the stigma here described to appear first is shown from the following facts: It is single and apparently common to all circulating, mature, nucleated erythrocytes. When more than one was observed, before the nucleus reacted to the stain, the rest were of a different nature as not found uniformly in all cells. It is either on the surface or very near it, as proved by the focusing of the microscope. It never shows brownian movements. Whenever such movements were described, they ought to belong to the granules that lie within the cytoplasm and, according to our observations, within the meshes of the reticulum. Whenever the single stigma was observed moving, the movements were not independent of the whole cell.

In commenting on these findings, it might be more expedient to consider separately the larger stigma. For, unlike the smaller stigma, it cannot be confused with any other element of the erythrocyte. Its property of taking the stain before all other stainable elements and the fact that it can be stained and demonstrated separately and alone prove conclusively and unmistakably its separate identity. 
Its affinity for supravital stains would show that it is related to the nucleus or the reticulum. However, unlike those structures, it stains deeply when the stain is present in a solution so weak that it cannot stain the nucleus or the reticular substance. It could be supposed that it reacts to the stain before all other elements because it dies first. Apparently this cannot be the case, for if the specimen is sealed and left over a period of time, it continues to show only these stigmata stained, and no other element. Further evidence pointing in the same direction is the fact that this stigma cannot be demonstrated in specimens counterstained with the Wright's stain.

It could not be proved whether this stigma is on the membrane or immediately below it. If it is on the membrane, it might indicate a hollow cavity where the stain accumulates, or an anomalous surface, possibly the point of separation of the erythrocyte from the mother or sister cell. It is diffcult to explain why this particular spot of the membrane reacts to weak solutions of vital stains while the remainder does not.

The observation that this stigma is connected by a thread, probably 'reticular,' with the nucleus and the fact that the nucleus takes up the stain before the reticulum reacts to the stain at all permit one to suppose, from a purely speculative point of view, that a microcanalicular system leads from the surface (membrane) of the cell to the nucleus first, then through the reticular meshes (if the reticulum is a preexisting structure) to the opposite surface of the membrane. This theory could support also the existence of the smaller stigma observed after nucleus and reticulum have been stained. If this be true, one might assume the existence of a minute circulatory system within the erythrocyte, extending from the first and larger stigma (the stoma) to the second and smaller stigma (the anus of the cell) : perhaps something of the nature of a Golgi apparatus, but quite dissimilar to the one Schilling(10) suggests. Thus the stain, or the nutritional substances, during life, may enter the cell and be 
eliminated through a definite route. Then the permeability of the cell 'membrane' would not be a required condition for the explanation of the different physiological phenomena of the erythrocytic cell. Certainly these theories are compatible with the fact that the stained reticulum may be washed free of stain with serum and restained many times, as proved in this laboratory $(20)$.

\section{SUMMARY}

A 'structure' in nucleated erythrocytes is here described that stains only supravitally, appearing as a deeply stained stigma that lies on the surface or 'membrane' of the cells. It is found in all the red blood cells of those animals in which nuclei are characteristic of the adult form. It is absolutely distinctive in its identity and is not to be confused with any other 'granules' or 'vacuoles.'

A second stigma is suspected to appear after the staining of the cell is apparently completed. This lies on the opposite side of the cell and is slightly smaller than the first.

The author wishes to express his appreciation to Dr. Cyrus C. Sturgis for supplying facilities and to Dr. Raphael Isaacs for valuable suggestions.

\section{BIBLIOGRAPHY}

1 Schultze, O. 1887 Die vitale Methylenblaureaktion der Zellgranula. Anat. Anz., Bd. 2.

2 Fischel, Alfred 1901 Untersuchungen über vitale Färbung. Anat. Hefte, Bd. 16, S. 415 .

3 Bremer, Ludwig 1895 Ueber das Paranuklearkörperchen der gekernten Erythrocyten, nebst Bemerkungen über den Bau der Erythrocyten im Allgemeinen. Arch. f. mikr. Anat. u. Entwkl., Bd. 45, S. 433.

4 Dehler, Adolup 1895 Beitrag zur Kenntniss des feineren Baues der roten Blutkörperchen beim Hühnerembryo. Ibid., Bd. 46, S. 414.

5 BRemer, Ludwig 1895 Die Identität des Paranuclearkörperchens der gekernten Erythrocyten mit dem Centrosom. Ibid., Bd. 46, S. 618.

6 Ranvier, L. 1875 Traité technique d'histologie, p. 192 . Parjs: F. Savy.

7 v. APÁtri, St, 1897 Protokollauszug der am 2, April 1897 abgehaltenen naturwissenschaftlichen Fachsitzung der medizinisch-naturwissenschaftlichen Sektion. Sitzgsber. d. med.-naturw. Sektion des Siebenbürg. Museumsvereins, Jahrg. 22, II, naturw. Abt. (Quoted by Meves in reference no. 9.) 
8 Weidenteich, Franz 1903 Die roten Blutkörperchen. Ergebnisse der Anatom. u. Entwickelungsgeschichte, Bd. 13, S. 1.

9 Meves, Frifdrich 1911 Gesammelte Studien an den roten Blutkörperchen der Amphibien. Arch. f. mikr. Anat., Bd. 77, S. 465 .

10 Schilding, Victor 1921 Die Zelltheorie des Erythrocyten als Grundlage der klinischen Wertung anämischer Blutbefunde. Arch. f. path. Anat. u. Phys., Bd. 234, S. 546.

11 Jolly, J. 1903 Origine nucléaire des paranuclei des globules sanguins du Triton. C. R. de l'Ass, des Anat., T. 5, p. 115.

$12 \ldots 1904$ Recherches expérimentales sur la division indirecte des globules rouges. Arch. d'Anat. Micr., T. 6, p. 455.

13 1923 Traité technique d'hematologie, p. 102. Paris: A. Maloine et Fils.

14 IsAacs, RAPHAEL 1925 The refractive granule red blood corpuscle. Its behavior and significance. Anat. Rec., vol. 29, pp. 299-313.

15 Jordan, H. E. 1925 A study of the blood of the leopard frog, by the method of supravital staining combined with the injection of India ink into the dorsal lymph sac, with special reference to the genetic relationships among leucocytes. Am. Jour. Anat., vol. 35, pp. 105131.

16 Lewis, MargareT T., AND Lewls, WARRen H. 1926 'Transformation of mononuclear blood-cells into macrophages, epithelioid cells, and giant cells in hanging drop blood-cultures from lower vertebrates. Contributions to Embryology, vol. 18, p. 96. The Carnegie Institution of Washington.

17 Chlopin, Nikolaus G. 1927 Experimentelle Untersuchungen über die sekretorisehen Prozesse in Zytoplasma. Arch. f. experimentelle Zellforschung, Bd. 4, S. 462.

18 DAW SON, ALDEN B. 1928 The 'segregation apparatus' of the amplibian erythrocyte and its possible relation to the Golgi apparatus. Anat. Rec., vol. 39, pp. 137-153.

19 - 1929 A further study of the reaction of the amphibian erythroeyte to vital dyes, osmic acid, and silver salts, with special reference to basophilia and reticulation. Anat. Rec., vol. 42, pp. 281-299.

20 Nirms, SAvas 1930 Supravital staining phenomena of reticulated erythrocytes. Folia Haematologiea, vol. 41, pp. 385-395. 